\title{
The Effect of Risk Management on Firm Value with Firm Performance as a Mediation (Study in Banking Industries Listed in IDX) for the year 2013-2017
}

\author{
Dippos Pasadena Situmorang* Yvonne Augustine \\ Faculty of Economic and Business, Trisakti University, Jl. Kyai Tapa No. 1 Grogol, West Jakarta 11440
}

\begin{abstract}
This study aimed to analyze the influence of Credit Risk and Operational Risk on Firm Value with Firm Performance as a mediation variable. With purposive sampling method obtained data from 35 Banking firms in Indonesia are taken from the Indonesia Stock Exchange 2013-2017 period. Using Structural Equation Modeling with AMOS program found that the Credit Risk and Operational Risk have a negative influence on Firm Value, Credit Risk and Operational Risk have a negative influence on Firm Performance, and Firm Performance have a positive influence on Firm Value. As a mediation variable, Firm Performance strengthen the influence of Credit Risk and Operational Risk on Firm Value significantly .
\end{abstract}

Keywords: Firm Value, Firm Performance, Risk Management, Tobin's Q, ROA, NPL, CER

DOI: $10.7176 / \mathrm{RJFA} / 10-8-01$

Publication date: April $30^{\text {th }} 2019$

\section{Introduction}

In the current era of globalization, business competition in various industries in Indonesia is getting tighter. The financial sector industry is also inseparable from competition in Indonesia. One of Company that is engaged in finance is the banking sector which plays an important role in economic system and the needs of other companies for funding needs. This is due to the fact that financial companies are indeed the main area of their services to provide funding facilities for other companies (Kasmir, 2012:3). According to Bank Indonesia Regulation No. $13 / 23 / \mathrm{PBI} / 2011$ concerning the application of risk management for the Bank, the risk is the potential loss resulting from a certain event. Meanwhile, the risk of loss that occurs as a direct or indirect consequence of the risk event, the loss can be in the form of financial and non-financial. Banking also has the potential to face these risks. Problems that occur in banking institutions in Indonesia related to the implementation of risk management are the inconsistency in the application of risk management in banking institutions (Loayza, 2014; and Zaini, 2015). The inconsistent implementation of risk management has resulted in the unpreparedness of banking institutions to face the financial crisis, which weaken firm value of the company from the investors perspectives.

\section{Literature Review}

\subsection{Agency Theory and Signaling Theory}

As an agent of principle who has the authority to manage the company, the management has the advantage with respect to the detailed information of the company. In accordance with the expectations of the principle that the company has a good performance in order to increase the size of companies and also the hidden personal goals, management can utilizes information for published in the truth or not (Jensen and Mackling, 1976). Some of the measures taken to improve the companies' performance is by manage credit risk and operational risk, with the aim to give a good signal in the market so the market give a good reaction on the firm value (Ross, 1977).

\subsection{Firm Value}

The value of the company is result from investor perception of the company which resulted in stock prices in the market. According to the theory of signal that the financial statements is one means of informative that explains the extent to which performance of the company, which the market demand and firms' supply are interact (Keown, 2006). Because of that, the management will try to show great performance in the market so as to get a positive reaction from the market.

\subsection{Firm Performance}

In general, firn performance is the company's ability to generate profits or profits. To measure the profit level of a company, a profit ratio or profitability ratio is used. The use of profitability ratios can be done using a comparison of the components in the financial statements. The measurement results can be used as management evaluation tools. Companies that have high profitability will attract investors to invest in hopes of gaining high profits. This ratio is considered by prospective shareholders because it will affect stock prices. 


\subsection{Credit Risk}

The Sustainable of the bank business is closely related to its productive assets, therefore bank management is required to always be able to monitor and analyze the quality of productive assets owned. The quality of earning assets shows the quality of assets in relation to the credit risk faced by banks due to the provision of credit and investment in bank funds. Productive assets that are assessed for quality include the planting of funds in both rupiah and foreign exchange, in the form of loans and securities (Siamat, 2005). Each bank's investment in earning assets is assessed for quality by determining the collectability level. Collectability can be interpreted as the state of repayment of principal, principal installments or loan interest by the customer as well as the level of possible return of funds invested in securities or other investments.

\subsection{Operational Risk}

Operational risk is a risk that arises due to the prevailing malfunction of the internal system, human error, system failure and external factors such as natural disasters, large demonstrations, etc. The source of the most extensive operational risk compared to other risks, in addition to being sourced from the above activities, also comes from operational activities and services, accounting, information technology systems, management information systems or human resource management systems. In general, operational risk is related to a number of problems that originate from the failure of a process or procedure. Operational risk is a risk that affects all business activities because it is an inherent matter in the implementation of a process or operational activity.

The purpose of this study is to examine the relationship between Credit Risk and Operational Risk to Firm Value with Firm Performance as Mediation Variabel on Banking Sector Listed in Indonsian Stock Exchange over the period of time (2013-2017). The study use Structural Equation Modelling as Tools Analysis on AMOS 16 Program.

Conceptual framework below explains the relationship model which explain that NPL and CER have direct influence on Tobin's Q and have indirect influence through ROA. In the framework, there are three pathways of influence as follow :

1. The direct influence of exogenous variables (NPL and CER) on endogenous variables (Tobin's Q) without going through mediator variable.

2. The influence of mediator variables (ROA) on endogenous variable (Tobin's $Q$ ).

3. The influences of exogenous variables (NPL and CER) on endogenous variables (Tobin's Q) through the mediator variables $(\mathrm{ROA})$.

\section{Method and Data}

The design of causal research has been used in this study, which the strength of relationships and influence among variables will be measured either directly or indirectly. Exogenous variables (NPL and CER), mediator variables (ROA) and endogenous variable (Tobin's Q) using one indicator each. Thus the overall study design includes 4 indicators in the initial model as shown above (see figure 1). Using secondary data of 28 samples out of 35 Bank listed at the end of December 2018 as the population, this research applied quantitative. The existing influences are studied simultaneously using Structural Equation Model (SEM). Sequences of analysis are presented in (figure 1)

Using the stages of modeling and analysis of structural equations into 7 steps, namely:

1. Development of a theoretical model;

2. Arrange path diagrams;

3. Change the path diagram into a structural equation;

4. Selecting the input matrix for data analysis;

5. Assess model identification

6. Assessing Goodness-of-Fit Criteria; 
Figure 1 : hypothesis framework

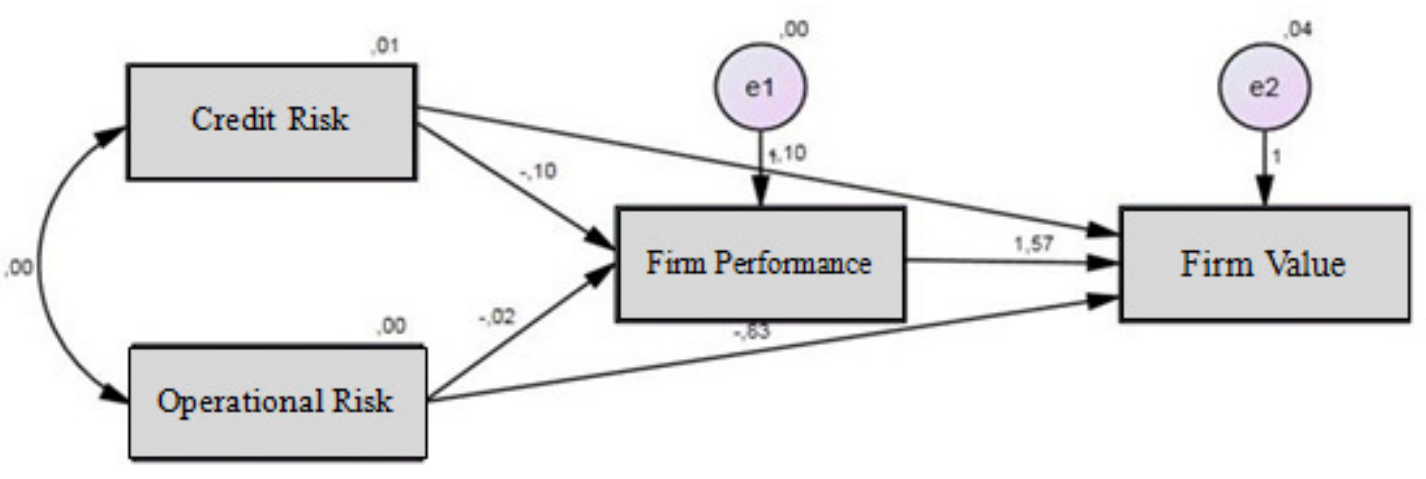

In this step an evaluation of the suitability of the model is carried out by examining the suitability of the model through a review of the various Goodness-of-Fit criteria, the order of which is

\begin{tabular}{|c|c|}
\hline Goodness of Fit Index & Cut Off Value \\
\hline Chi Square & Expected Small \\
\hline Significance Probability & $>0,05$ \\
\hline RMSEA & $<0,10$ \\
\hline NFI & $>0,90$ \\
\hline RFI & $>0,90$ \\
\hline TLI & $>0,90$ \\
\hline CFI & $>0,90$ \\
\hline
\end{tabular}

Source : Ghozali (2009)

\section{Results and Discussion}

\subsection{Descriptive Analysis}

\begin{tabular}{|c|c|c|c|c|}
\hline Variables & Mean & Minimum & Maximum & Std. Dev \\
\hline Tobin's Q & 1,0752 & 0,7494 & 1,9259 & 0,1928 \\
\hline ROA & 0,0195 & 0,0009 & 0,542 & 0,0115 \\
\hline NPL & 0,0225 & 0,0000 & 0,0854 & 0,0135 \\
\hline CER & 0,8209 & 0,3328 & 0,9904 & 0,1085 \\
\hline
\end{tabular}

Source : Analysis Result on SPSS 21

Tobin's $Q$ has a minimum value of 0,7494 and a maximum of 1,9259 while the mean value was 1,0752 smaller than the value of a standard deviation of 1,1928 which explains that the mean value can not be used to represent data Tobin's Q.

ROA has a minimum value of 0,0009 and a maximum of 0,542 while the mean value was 0,0195 and 0.0115 standard deviations which explains that the average ROA in Banking Indonesia has been quite good.

NPL has a minimum value of 0,0000 and a maximum of 0,0854 while the mean value was 0,0225 and 0.0135 standard deviations which explains that the average NPL in Indonesia has been mitigate well.

CER has a minimum value of 0,3328 and a maximum of 0,9904 while the mean value was 0,8209 and 0.1085 standard deviations which explains that the average CER in Indonesia has well organized with revenue.

\subsection{Goodness of Fit Test}

\begin{tabular}{|c|c|c|c|}
\hline Goodness of Fit Index & Cut Off Value & Value & Result \\
\hline Chi Square & Diharapkan Kecil & 4,439 & Goodness of Fit \\
\hline Significance Probability & $>0,05$ & 0,000 & Marginal Fit \\
\hline RMSEA & $<0,10$ & 0,013 & Goodness of Fit \\
\hline NFI & $>0,90$ & 0,913 & Goodness of Fit \\
\hline RFI & $>0,90$ & 0,950 & Goodness of Fit \\
\hline TLI & $>0,90$ & 0,837 & Marginal Fit \\
\hline CFI & $>0,90$ & 0,946 & Goodness of Fit \\
\hline
\end{tabular}

\section{Source : Analysis Result on Amos 16}

From the result above conclude that this study is suitable with Goodness of Fit test criteria, so the data could be moved to hypotesis test. 


\subsection{Hypotesis Analysis}

Direct Effect

\begin{tabular}{|c|l|c|c|c|c|}
\hline $\mathbf{H}$ & \multicolumn{1}{|c|}{ Hypotesis } & Estimate & P Value & Decision & Influance \\
\hline$H 1 a$ & $\begin{array}{l}\text { There is negative Influance of Credit Risk (NPL) } \\
\text { on Firm Performance (ROA) }\end{array}$ & $-0,103$ & 0,000 & Accept Ha & Significant \\
\hline$H 2 a$ & $\begin{array}{l}\text { There is negative Influance of Operational Risk } \\
(\text { CER) on Firm Performance (ROA) }\end{array}$ & $-0,025$ & 0,000 & Accept Ha & Significant \\
\hline$H 3 a$ & $\begin{array}{l}\text { There is negative Influance of Credit Risk (NPL) } \\
\text { on Firm Value (Tobin's Q) }\end{array}$ & $-0,110$ & 0,002 & Accept Ha & Significant \\
\hline$H 4 a$ & $\begin{array}{l}\text { There is negative Influance of Operational Risk } \\
\text { (CER) on Firm Value (Tobin's Q) }\end{array}$ & $-0,829$ & 0,000 & Accept Ha & Significant \\
\hline$H 5 a$ & $\begin{array}{l}\text { There is positive Influance of Firm Performance } \\
\text { (ROA)on Firm Value (Tobin's Q) }\end{array}$ & 1,571 & 0,005 & Accept Ha & Significant \\
\hline
\end{tabular}

\section{Source : Analysis Result on AMOS 16}

Significant path coefficients indicate the magnitude of the direct effect of NPL, CER and ROA as follows:

1. NPL has direct influence on ROA by $-0,103$. This means that 1 unit increase in NPL is expected to decrease ROA by $-0,103$ unit, ceteris paribus,

2. CER has direct influence on ROA by $-0,025$. This means that 1 unit increase in CER is expected to decrease ROA by $-0,025$ unit, ceteris paribus,

3. NPL has direct influence on Tobin's $\mathrm{Q}$ by $-0,110$. This means that 1 unit increase in NPL is expected to decrease Tobin's Q by - 0,110 unit, ceteris paribus,

4. CER has direct influence on Tobin's $Q$ by $-0,829$. This means that 1 unit increase in CER is expected to decrease Tobin's Q by $-0,829$ unit, ceteris paribus,

5. ROA has direct influence on Tobin's Q by 1,571. This means that 1 unit increase in ROA is expected to increase Tobin's Q by 1,571 unit, ceteris paribus,

Indirect Effect

\begin{tabular}{|c|l|c|c|c|c|}
\hline $\mathbf{H}$ & \multicolumn{1}{|c|}{ Hypotesis } & Estimate & P Value & Decision & Influance \\
\hline H6a & $\begin{array}{l}\text { There is negative indirect Influance of credit risk } \\
\text { (NPL) on Firm Value (Tobin's Q) through firm } \\
\text { performance (ROA) }\end{array}$ & $-0,012$ & 0,000 & Accept Ha & Significant \\
\hline$H 7 a$ & $\begin{array}{l}\text { There is negative indirect Influance of operational } \\
\text { risk (CER) on Firm Value (Tobin's Q) through } \\
\text { firm performance (ROA) }\end{array}$ & $-0,032$ & 0,000 & Accept Ha & Significant \\
\hline
\end{tabular}

Source : Analysis Result on AMOS 16

Significant path coefficients indicate the magnitude of the indirect effect of NPL and CER as follows:

1. NPL has indirect influence on Tobin's $Q$ through ROA by $-0,012$. This means that 1 unit increase in NPL is expected to decrease Tobin's Q through ROA by -0,012 unit, ceteris paribus,

2. CER has indirect influence on Tobin's $Q$ through ROA by $-0,032$. This means that 1 unit increase in CER is expected to decrease Tobin's Q through ROA by $-0,032$ unit, ceteris paribus,

\section{Conclusions, Limitations and Suggestions}

\subsection{Conclusions}

Based on the discussion of the results of hypothesis test that Credit Risk and Operational Risk has a negative influence on firm value, where the company's risk management activities in mitigate risk that might arise in the future get a bad response from investors. Unlike with firm performance that result a positive influence on firm value, mean good performance of company make value added on the firm value. Furthermore, firm performance can moderate influance of credit risk and operational risk to firm value. Where in implementing risk management, risk committee must be able to set the maximum risk limit that can be tolerated, so that it doesn't reduce firm performance and firm value in the perspectives of investors.

\subsection{Limitations and Suggestions}

Total observation period is only 5 years so it is not strong enough to generalize the results, it would be better if the observations were made longer for future research so that the result will be more robust in confirming the theory and previous research. The Object of study is limited to Banking Industry that listed in IDX, so for future research could use all Bank either listed or notlisted in IDX.

This study only use 2 variabel to describe financial management risk, for future research could use other variable that could represent financial risk management like debt structure, market risk, liquidity risk, etc. for future research could added some intervening variable like Earnings Management or Tax Planning, to find the 
effect of it's variable.

\section{References}

Anthony, N. Robert dan Govindarajan, Vijay. (2011). Sistem Pengendalian Manajemen. Edisi 12. Tanggerang: Karisma Publishing Group.

Ayuningrum, Anggrainy Putri. (2010). Analisis Pengaruh CAR, NPL, BOPO, NIM dan LDR Terhadap ROA (Studi Kasus pada Bank Umum Go Public yang Listed pada Bursa Efek Indonesia tahun 2005-2009). (Tidak dipublikasikan). Semarang : Universitas Diponegoro.

Bambang, Riyanto. (2001). Dasar-Dasar Pembelanjaan Perusahaan, Edisi Keempat, Cetakan Ketujuh, Yogyakarta :BPFE.

Baridwan, Zaki. (2010). Intermediate Accounting. Edisi Ketujuh. Yogyakarta: Badan Penerbit Fakultas Ekonomi Universitas Gajah Mada.

Dahlan, Siamat, (2005). Manajemen Lembaga Keuangan. "Kebijakan Moneter dan Perbankan”, Edisi 1. Jakarta : Fakultas Ekonomi Universitas Indonesia.

Dendawijaya, Lukman, (2005). Manajemen Perbankan, Edisi Kedua, Cetakan Kedua,Bogor :Ghalia Indonesia

Ghozali, Imam. (2009). Aplikasi Analisis SEM dengan Program AMOS. Edisi 4.Semarang: Badan Penerbit Universitas Diponegoro.

Gujarati, Damodar. 2006. Dasar-Dasar Ekonometrika. Jakarta: Erlangga.

Harahap, Syofran Syafri, (2003), Teori Akuntansi, Edisi Revisi, Jakarta: Grafindo.

Husnan, Suad. (2010). Manajemen Keuangan Teori Dan Penerapan (Keputusan Jangka Panjang). Edisi Keempat. Yogyakarta :BPFE.

Ikatan Akuntan Indonesia. (2015). Standar Akuntansi Keuangan. Jakarta : Salemba Empat.

J. Brines. (2004). Analysis of Residuals. Jurnal Sociology 429.

Jensen, Michael C. dan William Melking. (1976). Theory of the Firm: Managerial, Behavior, Agency Costs and Ownership Structure. Journal of Financial Economics, Volume 3.

Kasmir. (2012). Analisis Laporan Keuangan. Cetakan Kelima. Jakarta: Rajagrafindo Persada

Kristaung, Robert, and Yvonne Augustine. (2018). Metodologi Penelitian Bisnis dan Akuntansi. Edisi Kedua. Dian Rakyat. Jakarta

Arthur J. Keown, John D. Martin, J. William Petty, David F. Scott. JR, (2005). Financial Management. Prentice Hall.

Loayza, N. (2014). Indonesia dinilai memiliki upaya yang baik dalam menghadapi krisis finansial. www.voaindonesia.com

Malayu, H; S.P. Hasibuan. (2007). Manajemen Sumber Daya Manusia. Jakarta : Cetakan 9. PT. Bumi Aksara.

Meythi, (2005). "Rasio Keuangan Yang Paling Baik Untuk Memprediksi Pertumbuhan Laba: Suatu Studi Empiris Pada Perusahaan Manufaktur Yang Terdaftar Di Bursa Efek Jakarta”, Jurnal Ekonomi dan Bisnis, Volume XI, Nomor 2, Fakultas Ekonomi Universitas Kristen Satyawacana, Salatiga.

Muchdarsyah. Sinungan, (2008), Produktivitas Apa dan Bagaimana, Jakarta: PT. Bumi Aksara.

Munawir, S. (2010). Analisa Laporan Keuangan. Yogyakarta : Liberty.

Payamta, M. Machfoedz. (1999). "Evaluasi Kinerja perusahaan Perbankan Sebelum dan Sesudah menjadi Perusahaan Publik di BEJ". Kelola, No, 20/VII, 1999.

Peraturan Menteri Perdagangan nomor : 46/M-DAG/PER/9/2009 tentang Perubahan Atas Peraturan Menteri Perdagangan Republik Indonesia nomor: 36/MDAG/PER/9/ 2007 tentang Penerbitan Surat Ijin Usaha Perdagangan (SIUP)

Ross, S.A. (1977) The Determination of Financial Structure: The Incentive-Signaling Approach. The Bell Journal of Economics, 8, 23-40.

Sugiyono. (2009). Metode Penelitian Bisnis. Bandung: CV ALFABETA. (2010). Metode Penelitian Kuantitatif Kualitatif \& RND. Bandung : Alfabeta.

Surat Edaran BI No.3/30/DPNP tanggal 14 Desember 2001.

Suwardjono. (2010). Teori Akuntansi: Pengungkapan dan Sarana Interpretatif. Edisi Ketiga. Yogyakarta : BPFE. Timothy A. Krause, Yiuman Tse. (2015). Risk Management and firm value : recent theory and evidence.

Undang-Undang Republik Indonesia Nomor 20 Tahun 2008 Tentang Usaha Mikro, Kecil, dan Menengah Veithzal Rivai. (2007). Bank and Financial Institute Management. Jakarta: PT. Raja Grafindo Persada.

Zaini, Zulkifli. (2015). Hadapi era baru bank konvensional dan syariah harus tingkatkan kualitas Manajemen Risiko. www.finansial.bisnis.com

http://www.republika.co.id/berita/koran/pareto/15/06/01/np9a882-profitabilitas bank-dalam-tekanan

(Accessed 20 January 2019)

www.idx.co.id (Accessed 20 January 2019) 